\title{
Entrepreneurship research (2000-2014) in the top six Brazilian journals of administration: gaps and directions
}

\author{
ANTONIO BENEdito de OLIVEIRA JUNIOR ${ }^{12}$ \\ Cristiane Chaves Gattaz ${ }^{3}$ \\ Roberto CARLOS Bernardes ${ }^{3}$ \\ EDSON SADAO IIZUKA 3
}

\author{
1 UnIVERSIDAde ANHEMBI MORUMBI (UAM) / EAD LAUREATE INTERNATIONAL UNIVERSITIES, SÃo PAULO - SP, BRAZIL \\ ${ }^{2}$ FACULdAdes Metropolitanas Unidas (FMU) / EAD LAUREATE INTERNATIONAL UNIVERSITIES, SÃO PAULO - SP, BRAZIL \\ ${ }^{3}$ Centro Universitário Fel (FEl), SÃo Paulo - SP, BrazIL
}

\begin{abstract}
This article presents a systematic review of entrepreneurship research published in the Top six Brazilian Journals of Administration (TBJA) - Revista de Administração de Empresas, Revista de Administração, Revista de Administração Contemporânea, Brazilian Journal of Public Administration, Brazilian Administration Review, and Organização \& Sociedade, during the period 2000-2014. It aims to identify gaps and directions for Brazilian entrepreneurship research to become a relevant area within the field of Administration. The results highlighted the following gaps: (i) few entrepreneurship publications within the TBJA; (ii) impact of the TBJA production is low compared to international journals focused exclusively on entrepreneurship; (iii) prevalence of qualitative methodological approaches. As directions, the results show: (i) to give preference to empirical studies carried out by rigorous methodologies (longitudinal, secondary data and experimental design); (ii) realization of empirical studies extending the theoretical basis of the existing literature; (iii) establishment of entrepreneurship research lines in Master/Doctoral Programs. This article contributes theoretically by identifying research gaps and directions, and by conducting a critical analysis of the entrepreneurship research and practice to give a perspective to researchers and first time authors to produce high impact papers.
\end{abstract}

Keywords: Entrepreneurship. Scientific high impact. Systematic review. Co-citation analysis.

\section{Pesquisa em empreendedorismo (2000-2014) nas seis principais revistas brasileiras de administração: lacunas e direcionamentos}

\section{Resumo}

Esta pesquisa fez uma revisão sistemática de pesquisas sobre empreendedorismo publicadas nas seis Principais Revistas Brasileiras de Administração (PRBA) - Revista de Administração de Empresas, Revista de Administração, Revista de Administração Contemporânea, Revista de Administração Pública, Brazilian Administration Review e Organização \& Sociedade, durante o período 2000-2014, procurando identificar desafios e oportunidades. Os resultados indicam como desafios: (i) poucos artigos de empreendedorismo publicados nas PRAB; (ii) o impacto da produção científica das PRAB é baixo comparativamente às revistas internacionais focadas em empreendedorismo; (iii) prevalência de abordagens metodológicas qualitativas. Como oportunidades: (i) dar preferência a estudos empíricos realizados com metodologias rigorosas (longitudinais, dados secundários e experimentos); (ii) realização de estudos empíricos que estendem a base teórica da literatura existente; (iii) criação de linhas de pesquisa em empreendedorismo no mestrado/doutorado. Este trabalho contribui teoricamente ao indicar lacunas e direcionamentos na área e ao fazer uma análise crítica da pesquisa e prática do empreendedorismo, dando uma perspectiva aos pesquisadores e autores iniciantes para produzirem artigos de alto impacto.

Palavras-chave: Empreendedorismo. Alto impacto científico. Revisão sistemática. Análise de cocitação.

\section{Investigación sobre iniciativa empresarial(2000-2014)en lasseisprincipalesrevistasdeadministraciónbrasileñas:} lagunas y direcciones

\begin{abstract}
Resumen
Esta investigación realizó una revisión sistemática de los estudios sobre iniciativa empresarial publicados en las seis Principales Revistas de Administración Brasileñas (PRAB) - Revista de Administração de Empresas, Revista de Administração, Revista de Administração Contemporânea, Revista de Administração Pública, Brazilian Administration Review y Organização \& Sociedade - durante el periodo 2000-2014, para la identificación de desafíos y oportunidades. Entre los desafíos se encuentran: (i) la existencia de pocos artículos científicos sobre el tema "iniciativa empresarial" publicados en las PRAB; (ii) el impacto de la producción científica de las PRAB es bajo en comparación con las revistas internacionales direccionadas al tema "iniciativa empresarial". (iii) la prevalencia de los enfoques metodológicos cualitativos. Entre las oportunidades se observa: (i) dar preferencia a los estudios empíricos realizados con metodologías rigorosas (datos secundarios, longitudinales y experimentos); (ii) la realización de estudios empíricos que extiendan la base teórica de la literatura existente; (iii) la creación de líneas de investigación sobre iniciativa empresarial en el programa de maestría y doctorado. Este trabajo contribuye teóricamente al indicar las lagunas y direcciones en el área y al hacer un análisis crítico de la investigación y la práctica de la iniciativa empresarial, proporcionando una perspectiva a los investigadores y autores iniciantes para producir artículos de alto impacto.
\end{abstract}

Palabras clave: Espíritu empresarial. Alto impacto científico. Revisión sistemática. Análisis de cocitación. 


\section{INTRODUCTION}

Entrepreneurship is widely regarded as one of the gears of economic growth (LUMPKIN and DESS, 1996) and a social, political, and economic response to an economy dictated by dominance of knowledge as a product factor, and also by 'entrepreneurship capital' as a complementary factor. Entrepreneurship capital here understood as the capacity to create and engage in entrepreneurial activity (AUDRETSCH and THURIK, 2004), which is a critical source of competitive advantage (BARNEY, 1991), especially in an increasingly challenging environment. According to management scholars, entrepreneurship is an emerging research field and is gaining importance in the international scene, mainly since the 1990s (LANDSTRÖM, HARIRCHI and ÅSTRÖM, 2012).

An unrestricted search of EBSCOhost using entrepreneurship as a keyword produces more than 97,000 articles, and of Google Academic, more than 1.5 million, yet reviews and meta-analyses are rare and narrowly focused, either on the level of analysis (individual, region, nation) (SU, ZHAI and LANDSTRÖM, 2015) or the type of subject (organizational mode, individuals and teams, environment, opportunities) (BUSENITZ, PLUMMER, KLOTZ et al., 2014), which results in the fragmentation of the field ultimately impeding its consolidation. However, entrepreneurship articles show signs of legitimacy to the field with publications in mainstream international journals of Administration: Academy of Management Journal (AMJ), Academy of Management Review (AMR), Strategic Management Journal (SMJ), the Journal of Management (JOM), Organization Science (OS), Management Science (MS), and Administrative Science Quarterly (ASQ) (BUSENITZ, PLUMMER, KLOTZ et al., 2014).

Entrepreneurship research as an intellectual production is about 30-40 years-old and has become an important area of academic research (LANDSTRÖM, HARIRCHI and ÅSTRÖM, 2012). In Brazil, the entrepreneurship field is much younger (beginning around the 1990s), and the scenario is quite different, since the research on entrepreneurship still seems innocuous and fledgling (INÁCIO JÚNIOR, MACHADO, GIMENEZ et al., 2014). Bertero, Vasconcelos, Binder et al. (2013) reinforce that Brazilian scientific production of the 2000s is deficient and immature. Thus, systematic review on entrepreneurship reinforces the need for reflection in terms of what has been done in the theoretical field, as well as in terms of practical relevance, in order for authors to publish high impact articles. Systematic review is a recognized method for analyzing the evidence-based literature and it is used as a guide to the development of research, indicating the main areas studied and possible gaps for future research (LORZ, MULLER and VOLERY, 2013).

From 2000 to 2014, 72 entrepreneurship articles were published in the Top Brazilian Journals of Administration (TBJA): Revista de Administração de Empresas (RAE), Revista de Administração (RAUSP), Revista de Administração Contemporânea (RAC), Revista de Administração Pública (RAP), Brazilian Administration Review (BAR), and Organização and Sociedade (O\&S) with the highest degree (A2), in the Brazilian Journals of Administration, by the evaluation of Brazilian Higher Education Personnel Improvement Coordination (CAPES) both in 2012 and 2014. During the period of 2011-2014, the publication of entrepreneurship articles (37) excelled since the period of 2000-2010, which may indicate that the field in Brazil is gaining more space in TBJA and that closer inspection is needed. An article published in the International Journal of Entrepreneurship conducted an analysis of academic publications on entrepreneurship during the period of 1980-2010 (INÁCIO JÚNIOR, MACHADO, GIMENEZ et al., 2014). The article, however, did not consider the six TBJA and did not cover the period of 2011-2014, also it did not conduct a critical analysis of the scientific production.

Therefore, there is a gap for critical analysis on entrepreneurship in the TBJA, especially if taking into account the pressure of CAPES and Higher Education Institutions (HEls) for publication and performance showing concrete evidence and providing unified parameters for comparison that can be useful to authors and HEls. For example, among the evaluation criteria for obtaining the HEls' grade with post-graduate programs in CAPES (2012), in the case of Administration, the greatest weight falls on publications, which represent $52.5 \%$ of the total grade. If we consider that the TBJA cover general topics, the feedback of submitted articles is time consuming, the need for publication is pressing.

The aim of this article is to describe and critically analyze the entrepreneurship research in the TBJA during 15 years (20002014), trying to identify gaps in Brazil's entrepreneurship research as directions for entrepreneurship to become a relevant area within Administration. To achieve this goal, a quantitative, qualitative and co-citation analysis was carried out, using a systematic review of all entrepreneurship articles published in the TBJA, a total of 72 articles analyzed. Thus, the research 
question is: What are the gaps and possible future directions within entrepreneurship research during the period of 20002014 in the TBJA?

This study has two main contributions. Firstly, it offers a quantitative and qualitative perspective reflecting the research field. The analysis of Brazilian research on entrepreneurship helps to identify gaps and directions, by indicating issues where research is under development in order to consolidate the field in Brazil, and by giving some direction for future research on entrepreneurship, building it as a relevant area within Administration. Secondly, it gives a new perspective to researchers and aspiring authors to improve their research, and also to improve the impact of their work. Thus, this study can help researchers who are exclusively or mainly focused on entrepreneurship as well as those who see entrepreneurship as a secondary area of research and seek new opportunities to join a new research field.

\section{ENTREPRENEURSHIP: A GROWING RESEARCH FIELD}

Entrepreneurship as an intellectual field has a long history dating back to the eighteenth century, even though more systematic entrepreneurship research began in the 1970s and 1980s (LANDSTRÖM and BENNER, 2010). Entrepreneurship research can be split into three main approaches: (1) economic; (2) social science; and (3) management studies (LANDSTRÖM and BENNER, 2010).

\section{Economic}

The economic era (1870-1940) represents the beginning of entrepreneurship research. Three main authors represent this era: (1) Knightian view (American); (2) Schumpeterian tradition (German); and (3) Kirznerian view (Austrian). In the Knightian tradition, entrepreneurship is mainly characterized by true uncertainty, that is, the entrepreneurs receive a return for making decisions under conditions of non-insurable uncertainty (LANDSTRÖM and BENNER, 2010). While Schumpeter views entrepreneurship as "the fundamental phenomena of economic development" (SCHUMPETER, 1934). The seminal work of Schumpeter (1934) was the breaking point of this time. The basic assumption was that economic growth resulted from innovation or "new combinations". Innovations take the form of new products, production methods, and new organization structure in the industry.

This innovation was implemented by entrepreneurs with a specific personality driven by a desire to find a private kingdom (power), will to conquer (succeed) by joy of creating (get things done) (SCUMPETER, 1934). The Kirzneriam tradition views the entrepreneur as a function that involves the coordination of information, which is based on identifying the gap between supply and demand, making it possible to earn money from this difference. Thus, the entrepreneur tries to discover profit opportunities and helps to restore equilibrium on marketing by acting on these opportunities (LANDSTRÖM and BENNER, 2010).

\section{Social science}

After the economic era, entrepreneurship was driven by social science (1940-1970) especially by the knowledge platforms which were influenced by two main approaches - sociological and psychological. The psychological approach focused on traits and categories of the entrepreneur, while the sociological focused on ethnicity, culture, and network (LANDSTRÖM and BENNER, 2010).

Influential contribution to this era came from McClelland's (1961) seminal work "The achieving society" showing that the values that prevail in each society are very important for its economic development. This is characterized by a lower focus on institutional norms and greater focus on openness toward other people representing economically better developed nations. The entrepreneur is the driving force in the economic growth of the country's development.

\section{Entrepreneur}

In the beginning, the research on entrepreneurship was heavily dominated by the entrepreneur's interest as an individual (personality and traits), characterized by a high need for risk-taking, internal locus of control, achievement, values and tolerance 
of ambiguity (SANTOS, CAETANO, MITCHELL et al., 2017). The studies sought to identify the taxonomy of entrepreneurs, the study of socioeconomic and cultural conditions favorable to the emergence of the entrepreneur differentiated nonentrepreneurs from entrepreneurs. However, this strand of research was heavily criticized.

According to Gartner (1985), focusing on the figure of the entrepreneur, without giving appropriate attention to the differences between the businesses they create and develop, could prove innocuous or fruitless. Thus, there was a breakdown of this paradigm in research on entrepreneurship which began to focus on the entrepreneurial process and behavior, as well as on the organizational factors that propel or impede it, in the late 1980s and early 1990s (SANTOS, CAETANO, MITCHELL et al., 2017).

An influential contribution to this breakdown was Gartner's (1988) seminal work "'Who is an entrepreneur?' Is the wrong question". Gartner envisioned the field of entrepreneurship as a set of new venture creation framework. After Gartner (1988), a great number of scholars have paid attention to the entrepreneurial process and behavior, which since the early 1990s, has become an important part of research on entrepreneurship. Moreover, the concept of entrepreneurship has been broadened by including activities and practices in order to identify new opportunities.

\section{Social network}

Different structures of relationships and network, drive the creation of new business and enterprises by reducing the barriers to enter the market, obtaining access to resources necessary to grow the business, identifying possible partnerships; reaching new customers and international markets (GRANOVETTER, 2005). Social network analysis is a tool for connecting macro and micro levels of sociological theory (GRANOVETTER, 1973).

An influential contribution to this strand is the seminal work of Granovetter (1973) "The strength of weak ties", where he analyzes the power of two ties: (1) weak - which is found in social networks that are more fragmented and porous, allowing the access to asymmetrical information, and capable of connecting an individual to different realities; (2) strong - found in close, united, and cohesive social networking which is capable of generating confidence and solidarity. Granovetter (1973) brought attention to the fact that most network models deal only with strong ties, however, the emphasis on weak ties is very important to entrepreneurs. He points out that "the personal experience of individuals is closely bound with larger-scale aspects of social structure, well beyond the purview or control of particular individuals" (GRANOVETTER, 1973, p. 1377).

Granovetter (1985) expands his theoretical propositions, introducing the concept of embeddedness of economic behavior, when he saw economy as a differentiated sphere in the modern industrial society that is defined by rational calculation of individual gain. The author points out that to understand the behavior of an entrepreneur in a holistic way, it is necessary to know their personal relationship structures and the way these personal relationships fit into a broader structure of social relationships. Moreover, if such behavior is instrumental or rational, we should consider that economic goals are not the main interest for entrepreneurs and enterprises, but also elements such as power, status, approval, and sociability (GRANOVETTER, 1985).

\section{Management studies}

Entrepreneurship research as a field is about 40 years old (since the 1970 s to the present day) and has become an important area of intellectual activity involving thousands of scholars. The seminal work of Shane and Venkataraman (2000) "The promise of entrepreneurship as a field of research" is one of the most influential works in this era. They point out that the field was lacking conceptual framework and it was necessary to incorporate the views and information gained from different disciplines in social science (vantage points) to build a systematic body of information on entrepreneurship (SHANE and VENKATARAMAN, 2000). The 1990s was the growth phase of entrepreneurship research and the field expanded with studies on migration, mobilization, police orientation and ambition to understand the 'entire' phenomenon (LANDSTRÖM and BENNER, 2010).

Shane and Venkataraman (2000, p. 218) define the field of entrepreneurship as "the scholarly examination of how, by whom, and with what effects opportunities to create future goods and services are discovered, evaluated and exploited". Thus, it involves the study of sources of opportunities, and the processes of discovery, evaluation and exploitation of opportunities. In addition, it involves the group of individuals who discover, evaluate and exploit these opportunities (SHANE and VENKATARAMAN, 2000). 
In Stevenson's view, entrepreneurship means much more than starting new business. Entrepreneurship is the process by which individuals, whether within their own organization or others, seek opportunities without taking into account the resources they currently control (STEVENSON and JARILLO, 1990). Miller and Friesen (1982) argue that an entrepreneurial organization is conceptually opposite to conservative company that is reluctant to innovate. Both Stevenson and Jarillo (1990) and Miller and Friesen (1982) agree that the entrepreneurial management should be understood as a management model different from traditional management. Over the years, several strands of research focusing on entrepreneurship have emerged, such as: entrepreneurial intention, entrepreneurial orientation, entrepreneurship education, and social entrepreneurship (SANTOS, CAETANO, MITCHELL et al., 2017).

\section{Entrepreneurial intention}

Intentions are a state of mind directing a conscious thought of a person toward a specific object outcome (or goal) and a path for achieving the outcome (means) (BIRD, 1988). Intention is a precursor of entrepreneurial action or a correlation between action and intention which is, in most empirical studies, moderate. Entrepreneurial Intention (EI) can be regarded as a key construct in the entrepreneur behavior and the venture creation process (SANTOS, CAETANO, MITCHELL et al., 2017).

Bird's (1988) study is one of the pioneers in this subject. She assumed that the process of El was based on the differences between individuals that operate through three mechanisms: (a) temporal tension - which involves connecting the present (what exists) to the future (intends to achieve, but not yet manifested); (b) strategic focus - which tends to be driven towards goals by differentiating the means and end-states, although both (means and ends) can be intentional; and (c) intentional posture - which reflects the individual's position related to their beliefs, needs, values and the outer world. Bird's proposition was quite static.

$\mathrm{El}$, whose models have been validated across many contexts and domains, has become one of the most developed subjects within entrepreneurship research. It was frequently based on the Theory of Planed Behavior (TPB) as the main theoretical framework. TBP involves three main pillars of intention: (1) individual's attitude towards behavior; (2) values people have about behavior - subjective form; and (3) control of the perceived behavior (SANTOS, CAETANO, MITCHELL et al., 2017).

\section{Entrepreneurial orientation}

Entrepreneurial Orientation (EO) is defined as a strategic process, a conceptual domain which includes some performance indicators, managerial preferences, behaviors, values and beliefs expressed by the top management (COVIN, GREEN and SLEVIN, 2006). The strand of research of the EO has received extensive conceptual and empirical attention in entrepreneurship research over the last 20 years (OLIVEIRA JUNIOR, BORINI, BERNARDES et al., 2016; SANTOS, CAETANO, MITCHELL et al., 2017). EO represents one of the few areas where it is possible to say that a cumulative body of knowledge has been developed (OLIVEIRA JUNIOR, BORINI, BERNARDES et al., 2016).

The early influential contribution to EO literature is Miller's (1983) seminal work "The correlates of entrepreneurship in three types of firms", which focuses on discovering the entrepreneurship key factors. He made a great contribution to the literature by pointing out that entrepreneurship is related to many variables such as: personality of the leader, strategy and structure of the firm and environment, and the relationships vary systematically and depend on the firm type (simple, planning, or organic) and not only on the entrepreneur. EO in Miller's (1983) view is a unidimensional construct with three dimensions (proactiveness, innovativeness and risk-taking), which was corroborated by Covin and Slevin (1989).

In the years that followed, there were many conceptual developments in the EO construct, especially by Lumpkin and Dess's (1996) seminal work, in which they included two more dimensions to the EO construct (autonomy and competitive aggressiveness) and, most importantly they considered EO as a multidimensional conceptualization with five dimensions (proactiveness, innovativeness, risk-taking, autonomy and competitive aggressiveness). EO should be measured with a reflexive model, and it exists as a continuous variable or as a set of variables represented by five dimensions (LUMPKIN and DESS, 1996; COVIN and LUMPKIN, 2011).

Since the 1990s, a large number of EO studies have been developed. These studies show a robust homogeneity that most of the studies are quantitative and use similar measurement models. However, after the 1990s this field has shown comparatively 
little conceptual development, although the research has been presented heterogeneity related to the conducting context (e.g. different types of sectors and organizations - small, medium, and large; using a great number of dependent and independent variables; and moderator and mediator factors). Moreover, over the last decade several state-of-the-art studies and metaanalyses have been developed to build a heavy cumulative body of knowledge within the area (RAUCH, WIKLUND, LUMPKIN et al., 2009; SANTOS, CAETANO, MITCHELL et al., 2017).

\section{Entrepreneurship education}

The Entrepreneurship Education (EE) stream of research has shown great growth within USA and European universities since the beginning of the 1990s, although there is still an intense debate on such education (SANTOS, CAETANO, MITCHELL et al., 2017). The systematic review of the methods used in EE made by Lorz, Muller e Volery (2013) show there are methodological deficiencies and question the overwhelmingly positive impact of EE indicating that "further research is necessary to better understand the potential influence of entrepreneurship programs on the participants' intentions, knowledge, and actions" (LORZ, MULLER e VOLERY, 2013, p. 145). They suggest that it is important to borrow methodologies from other fields (e.g. psychology and pedagogy) using quasi-experimental design for demonstrating causality; and training methods and teaching can be great opportunities to enhance the results of entrepreneurship programs (LORZ, MULLER e VOLERY, 2013). However, it is necessary to have a stronger theoretical anchor of the pedagogical approaches in entrepreneurship (SANTOS, CAETANO, MITCHELL et al., 2017).

One of the pioneers in studying EE was Gibb (1987). He defined the term "enterprise culture" by addressing the relationship between the concepts of entrepreneurship, enterprise and small business and the issue of whether entrepreneurship can be socially engaged through training and education.

\section{Social entrepreneurship}

Finally, another strand of research that is starting to receive great interest within entrepreneurial research is Social Entrepreneurship (SE). However, differently from other research lines within the field, SE does not have a cumulative body of knowledge or theoretical models. Dees (1998) is one of the pioneers in studying SE.

SE emerges from the problems and challenges that arise in society, such as hunger, poverty, lack of drinking water and electricity, illiteracy, among others. SE is organized in general by collective aspects, be it in its conception, construction, conduction or results reach. In this type of entrepreneurship there is a combination of market mechanisms and the social logic of action. In this sense, the dialogical practice between social entrepreneurs, members of civil society, governments and even private companies seems to be something inherent to this type of entrepreneurship (AUSTIN, STEVESON and WEI-SKILLERN, 2012; DEES, 1998; GODÓI-DE-SOUSA and FISCHER, 2012).

\section{Systematic review on entrepreneurship}

Systematic review on entrepreneurship research is about 30-40 years-old and has become an important area of intellectual activity involving thousands of scholars. In the case of Brazil, the field of entrepreneurship is much younger, starting in the 1990s. Thus, it is time to look back and analyze what has been published in TBJA and try to identify the main opportunities and challenges for researchers within the field in Brazil. It is beneficial to periodically reflect on the knowledge acquired in order to establish a basis for the future development of entrepreneurship as a research field (LANDSTRÖM, HARIRCHI and ÅSTRÖM, 2012).

Given the growing interest in the future of entrepreneurship research as a field, some recent studies have examined its scientific structure. For example, Busenitz, Plummer, Klotz et al. (2014) examined the entrepreneurship research that has been published in the top management journals, using a bibliometric technique. They found that there is growing convergence around several domains (mode of organizing, individuals and teams, environments, and opportunities) that comprise the majority of entrepreneurship research. Landström, Harirchi and Åström (2012) used bibliometric analysis to identify the 'knowledge producers' who have shaped the field of entrepreneurship over time and their core research and found that entrepreneurship is a changeable field of research, linked to disciplines such as 'management studies' and 'economics', but over time, the field has become formalized with its own core knowledge, research specialties and an increasing number of 
'insider works'. Nevertheless, it is still based on some old theoretical frameworks imported from mainstream disciplines and, in the period of 2000-2010, it was possible to see the emergence of a number of new field-specific theories and concepts.

Su, Zhai and Landström (2015) compared entrepreneurship research in China with USA and Europe using a bibliometric method based on publications in the Social Science Citation Index over the past 10 years, and showed that, on one hand, entrepreneurship research in China has much in common with that in the USA and Europe. However, they found that Chinese entrepreneurship research has its own uniqueness. Some context-specific topics attract scholarly attention in China, such as internationalization and contextualization, which are two areas that contribute to similarity and uniqueness respectively. Landström, Harirchi and Åström (2012), and Busenitz, Plummer, Klotz et al. (2014) argue that to successfully develop entrepreneurship research in the future, it is necessary to relate new research opportunities to previous knowledge within the field, which calls for a stronger 'knowledge-based' focus. Thus, a closer examination of articles published in TBJA can give important insights into the current state of these studies in Brazil.

\section{METHOD}

A systematic review requires clear definition of the search strategy, establishing the criteria for inclusion and exclusion of articles and a critical analysis of the quality of the articles (PETTICREW and ROBERTS, 2006). Although there is no consensus on how to develop a systematic review or bibliometric analysis, there are some steps to follow (BREI, VIEIRA and MATOS, 2014). Thus, a guideline was developed based on what has been done within the Brazilian systematic review context. The first step was to select the database for entrepreneurship and the journals to be included in the search. The following criteria were used: (1) include only TBJA with the highest impact factor in Brazil (A2 rating) using CAPES system in both years 2012 and 2014; (2) select only those journals with general editorial directives in all areas of Administration; (3) choose a period for analysis, which in this study was 2000 to 2014, to analyze the publications evolution in the field. The Brazilian Business Review and Gestão e Produção were not considered due to the fact that in 2014 they were downgraded from rating A2 to B1 (CAPES, 2015).

Following these criteria, the TBJA selected were RAC, RAE, RAUSP, RAP, BAR and O\&S. All articles studied were available on the journals' websites. The articles were selected through a systematic and comprehensive search by keywords, using the following terms: entrepreneurship (empreendedorismo), entrepreneur (empreendedor), entrepreneurial orientation (orientação empreendedora). To assure the scope of the articles, a search on SciELO (www.scielo.org) database was performed, considering the same period, journals, and keywords, confirming the data obtained directly from the journals' websites which represented a total of 72 entrepreneurship articles. Data collection was conducted in 2015 and analyzed during 2015 and 2016. To develop a good description and reliable analysis, Mendley software was used, which is a combination of desktop request and website, allowing to generate statistics on the selected articles (YAMAKAWA, KUBOTA, BEUREN et al., 2014).

An analytical framework was developed that included important information and categories per item, which can be classified into eight groups (Figure 1):

1. Articles: analyzed by year (2000-2014) and source (TBJA) of publication.

2. Impact Factor: classification of Brazilian and entrepreneurship international journals, according to the classification of SClmago Journal Rank (SJR, 2015). The choice of SJR was because it is the largest, best known and the first service to offer an open access alternative source of indicators to traditional Journal Citation Reports (JCR), which now belongs to Thomson Reuters, and requires a subscription to access data (JACSÓ, 2013). While the JCR contains more than 8,000 database journals in 171 categories and in the social sciences covers more than 2,900 journals in 55 subject categories (MUTHAMILARASAN and PRASAD, 2014), SJR covers about 20,000 journals and other periodicals compiled by Elsevier for Scopus database (JACSÓ, 2013).

3. Higher Education Institutions (HEIs): verification of the number of articles published by each HEl and whether the HEls with more than two articles published in the period (2000-2014), had an entrepreneurship center.

4. Main Authors: authorship ranked by number of publications and affiliated HEI (considering only the first affiliated institution). Later, it was verified if these authors consider entrepreneurship as a major area of research and have some 
article(s) published in entrepreneurship international journals selected in step (2) by looking at the curriculum of the major Brazilian producers on entrepreneurship who have published at least two articles in TBJA between 2000-2014.

5. Thematic Focus: each article was allocated according to the main approach used. When there was doubt about the main theme, the one with theoretical framework that had greater weight for the study was selected.

6. Co-citation Analysis: refers to the frequency of co-citation defined as the number of times two documents have been cited jointly in articles. In addition, a clustering routine was used to scrutinize all co-cited documents, looking for authors that are of interest and relevance to Brazilian researchers (SU, ZHAI and LANDSTRÖM, 2015).

7. Methodological Approach: the research methods used in the articles were organized in four main categories:

a. Type of study: classified as theoretical (without collection and/or data analysis), and empirical (with collection and/or data analysis).

b. Type of analysis: qualitative, quantitative or mixed (qualitative and quantitative).

c. Type of data: primary, secondary or mixed (primary and secondary).

d. Analysis technique: classified according to the information provided in the articles.

8. Structure of the Articles: the articles were read and the main structures (introduction, methodology, discussion and conclusion, etc.) analyzed.

Figure 1

\section{Steps of systematic review}

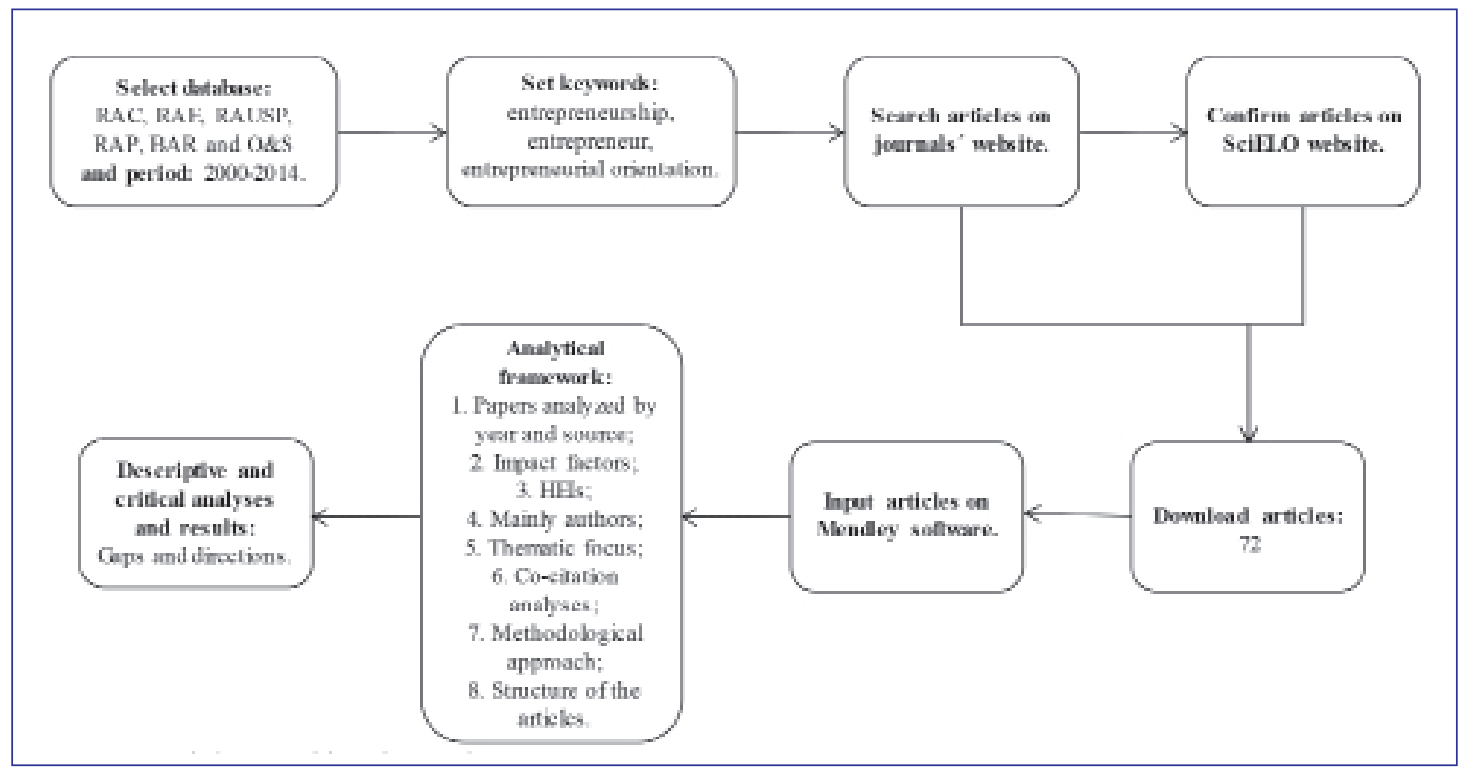

Source: Elaborated by the authors.

\section{RESULTS, ANALYSIS, AND DISCUSSION}

\section{Articles analyzed}

Analyzing the source of the articles (Figure 2) it was found that until 2005 the entrepreneurship research in Brazil was incipient. The total number of publications was only nine articles, where RAE emerged as the main journal. Since 2006, the publication has grown 367\% over the period 2000-2005. From 2006 to 2009 a productive period was observed, in which there was a quantitative evolution of entrepreneurship articles, with an average publication of five articles per year. In this period, RAC, with seven articles, began to emerge and exceed RAE (five articles) as the primary source of publications. Starting from 2010, the average production of the previous period increased to approximately nine articles per year. In 2014 production reached an unprecedented 16 articles, surpassing the previous record of 11 articles in 2012. 
During the period 2010-2014, RAC (16 articles) was the main journal for publishing entrepreneurship articles and RAUSP (13 articles) emerged as the runner-up. Considering the entire period 2000-2014, RAC accounted for 33.3\%, RAUSP 25\%, RAE 19.4\%, RAP 11.1\%, BAR 6.9\% and O\&S 4.2\% of Brazil scientific production on entrepreneurship. An important indication of the quality and legitimacy of research for all disciplines is its publications in leading academic journals. When the presence of an area in mainstream journals is limited, questions concerning accuracy, conceptual boundaries and acceptance as an academic topic seem to become major issues (BUSENITZ, PLUMMER, KLOTZ et al., 2014).

Figure 2

\section{Number of articles analyzed by year and source}

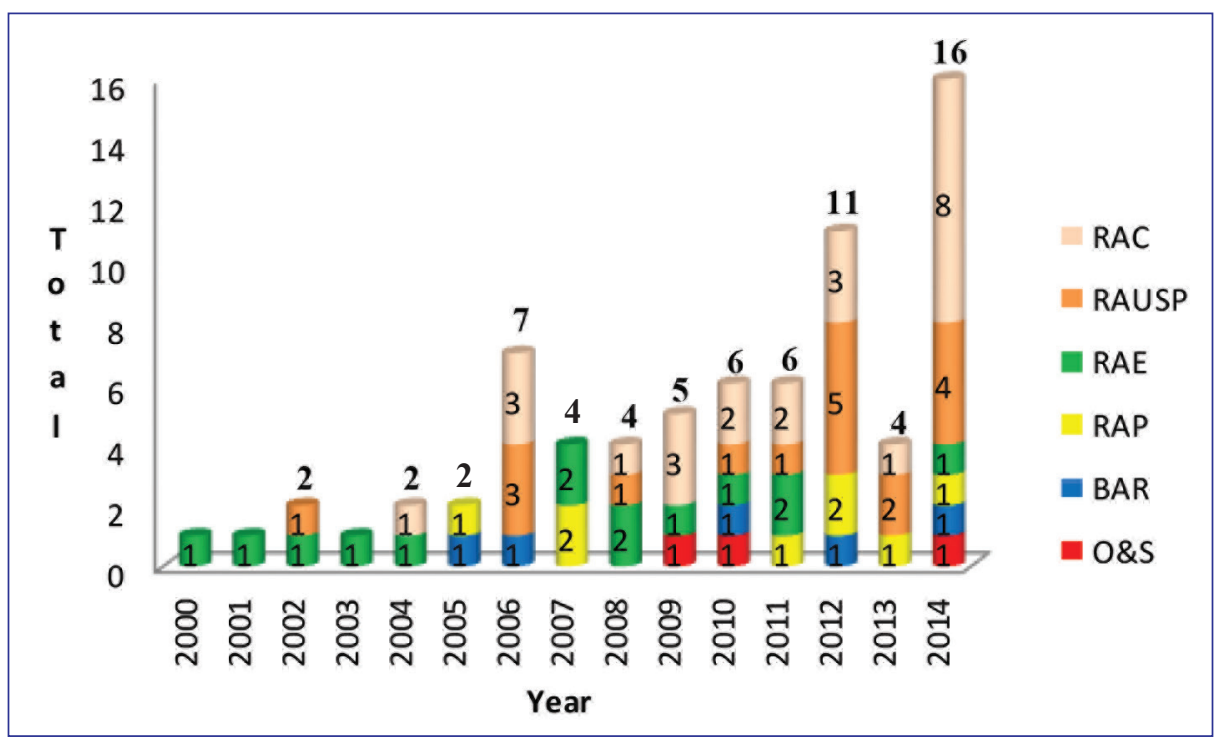

Source: Elaborated by the authors.

This scenario is most critical, in Brazil, due to the lack of academic journals with high quality dedicated exclusively to entrepreneurship. However, it should be considered that the entrepreneurship area is relatively new and the journals specializing in entrepreneurship are recent. Although the area presents several challenges, it may be an interesting field of research for development due to the many opportunities it offers. Research by Busenitz, Plummer, Klotz et al. (2014) indicated that nowadays entrepreneurship articles have a significant presence in mainstream international journals of Administration, showing signs of increasing legitimacy of entrepreneurship as a subject. In Brazil, perhaps a way to increase the impact of entrepreneurship in the area is the creation of calls for papers with special issues on entrepreneurship.

\section{Comparative of national and international journals' impact factors}

To check the impact of publications in TBJA, the criteria adopted by SJR (2016) was used, which include the SJR score, H Index, and citations per document for creating a classification of the impact factors. In addition, we verify the impact of international journals focused exclusively on entrepreneurship for comparison with TBJA using the same criteria. Table 1 presents the impact factors in Brazilian journals, ranking them according to SJR. Among the TBJA, RAE was ranked first (SJR $=.207$ ) and BAR $(S J R=.188)$ third. The Journal Gestão e Produção $(S J R=.193)$, B1 journal in CAPES classification, was ranked second.

These indicators show that the impact of Brazilian production is still low internationally, considering that some journals with lower classification according to CAPES (Qualis B1) have an impact factor on the same level as TBJA, and the other journals researched here (RAC, RAUSP, RAP and O\&S) are not listed in the SJR. This means that much still needs to be done in Brazilian academia for scientific production to have an effective national and international impact. 
Table 1

Impact factors of the Brazilian journals of administration

\begin{tabular}{c|l|c|c|c}
\hline \multirow{2}{*}{ Ranking } & \multirow{2}{*}{ Brazilian Journals of Administration } & \multicolumn{3}{|c}{ 2015 Impact Factors } \\
\cline { 3 - 5 } & & SJR & H Index & Cites/Doc. (2 years) \\
\hline 1 & RAE- Revista de Administração de Empresas & 0.207 & 6 & 0.46 \\
\hline 2 & Gestão \& Produção & 0.193 & 9 & 0.30 \\
\hline 3 & BAR- Brazilian Administration Review & 0.188 & 6 & 0.21 \\
\hline 4 & Revista Brasileira de Orientação Profissional & 0.168 & 3 & 0.04 \\
\hline 5 & Revista Brasileira de Gestão de Negócios & 0.15 & 4 & 0.16 \\
\hline
\end{tabular}

Source: SCImago Journal \& Country Rank (SJR, 2017).

Internationally, we observed that the journals focusing on entrepreneurship (see Table 2) which is best positioned in terms of index (considering SJR classification), would be very well ranked in Brazil (considering CAPES classification). The first 16 journals have impact factors ranging from 4.24 to 0.237 , which are higher than the TBJA. In terms of publications' influence, RAE (ranked first among nationals), would be in $17^{\text {th }}$ place between the 18 international journals of entrepreneurship. BAR would be in $18^{\text {th }}$ place.

Table 2

Impact factor of the international journals of entrepreneurship

\begin{tabular}{|c|c|c|c|c|c|}
\hline \multirow[b]{2}{*}{ Ranking } & \multirow[b]{2}{*}{ International Journals of Entrepreneurship } & \multicolumn{4}{|c|}{2015 Impact Factors } \\
\hline & & SJR & H Index & $\begin{array}{l}\text { Cites/Doc. } \\
\text { (2 years) }\end{array}$ & Country \\
\hline 1 & Entrepreneurship Theory and Practice & 4.240 & 80 & 4.133 & USA \\
\hline 2 & Strategic Entrepreneurship Journal & 3.377 & 12 & 2.919 & USA \\
\hline 3 & Entrepreneurship and Regional Development & 1.397 & 56 & 2.586 & UK \\
\hline 4 & Foundations and Trends in Entrepreneurship & 1.200 & 19 & 2.857 & USA \\
\hline 5 & $\begin{array}{l}\text { International Journal of Gender and } \\
\text { Entrepreneurship }\end{array}$ & 0.638 & 6 & 1.543 & UK \\
\hline 6 & Journal of International Entrepreneurship & 0.549 & 23 & 1.438 & NED \\
\hline 7 & $\begin{array}{l}\text { International Entrepreneurship and } \\
\text { Management Journal }\end{array}$ & 0.489 & 27 & 1.120 & USA \\
\hline 8 & Journal of Social Entrepreneurship & 0.446 & 10 & 1.500 & UK \\
\hline 9 & Journal of Entrepreneurship Education & 0.322 & 6 & 0.244 & USA \\
\hline 10 & $\begin{array}{l}\text { International Journal of Entrepreneurship and } \\
\text { Small Business }\end{array}$ & 0.294 & 16 & 0.770 & UK \\
\hline 11 & $\begin{array}{l}\text { International Journal of Entrepreneurship and } \\
\text { Innovation }\end{array}$ & 0.287 & 4 & 0.786 & UK \\
\hline 12 & $\begin{array}{l}\text { World Review of Entrepreneurship, } \\
\text { Management and Sustainable Development }\end{array}$ & 0.280 & 8 & 0.492 & UK \\
\hline 13 & Journal of Developmental Entrepreneurship & 0.271 & 13 & 0.727 & SIN \\
\hline 14 & Journal of Entrepreneurship & 0.253 & 8 & 0.429 & IND \\
\hline 15 & $\begin{array}{l}\text { International Journal of Entrepreneurship and } \\
\text { Innovation Management }\end{array}$ & 0.238 & 15 & 0.255 & UK \\
\hline 16 & $\begin{array}{l}\text { Journal of Research in Marketing and } \\
\text { Entrepreneurship }\end{array}$ & 0.237 & 2 & 0.158 & UK \\
\hline 17 & International Journal of Entrepreneurship & 0.167 & 5 & 0.188 & USA \\
\hline 18 & Academy of Entrepreneurship Journal & 0.165 & 5 & 0.007 & USA \\
\hline
\end{tabular}

Source: SCImago Journal Rank (SJR, 2017a). 
Therefore, the impact of TBJA is still limited, even when comparing to a specific area (entrepreneurship). Although there is more competition for publishing articles in international journals, there is a window of opportunity for Brazilian researchers to publish their work in entrepreneurship international journals.

Maybe with the impact of their international publications, TBJA can give more opportunities to the theme entrepreneurship and thus legitimize and consolidate as a promising field of research. However, for this to happen, Brazilian researchers need to carry out interesting studies with strong methodologies.

\section{Higher education institutions involved in research}

The total institutions involved (131) in entrepreneurship research is well above the 72 published articles. This can be a good indicator of growing interest with regards to conducting research in the area. The vast majority of articles were written by two or three authors (59.7\%), from different HEls, which suggests the use of complementarities or synergies between these authors and HEIs. In the classification of HEIs, FGV-SP ranks first in the number of articles (10 or 7.7\%). Together the $12 \mathrm{HEIs}$ represent $47.3 \%$ of all articles published suggesting some concentration, and this is evidence of a growing potential of research and publications in case other HEls increase their research efforts (see Table 3).

Table 3

Number of articles published by institutions

\begin{tabular}{c|l|c}
\hline Ranking & \multicolumn{1}{|c}{ Higher Education Institutions } & No. of Articles \\
\hline 1 & Fundação Getúlio Vargas (FGV-SP) & 10 \\
\hline 2 & Pontifica Universidade Católica (PUC-MG) & 9 \\
\hline 3 & Universidade de São Paulo (USP) & 8 \\
\hline 4 & Universidade Nove de Julho (Uninove) & 6 \\
\hline 5 & Universidade Federal do Rio Grande do Sul (UFRS) & 5 \\
\hline \multirow{2}{*}{6} & Pontifica Universidade Católica (PUC-SP) & 4 \\
& Universidade Estadual de Maringá (UEM) & 4 \\
\hline 7 & Universidade do Estado de Santa Catariana (UDESC) & 3 \\
\hline \multirow{2}{*}{8} & Centro Universitário FEl (FEI) & 3 \\
& Universidade Federal de Lavras (UFLA) & 3 \\
\hline & Universidade Federal de Pernambuco (UFPE) & 3 \\
\hline & HEC Montreal (CAN) & 69 \\
\hline
\end{tabular}

Source: Elaborated by the authors.

Note. ${ }^{*}$ In cases where the author was affiliated in two or more institutions when he published the article were considered as the first institution.

From the results in Table 3, the HEls with at least three articles published during the period 2000-2014 were checked to see which ones had an Entrepreneurship Center (EC). According to research by Hashimoto (2012), in Brazil there are 33 ECs, of which 22 are in the Southeast (66.7\%), and 15 in the State of São Paulo (45.5\%). Among the six best ranked HEls, PUC-MG, UFLA and UEM do not have an EC, but PUC-MG has a core research in entrepreneurship and enterprise networks within its Master and Doctoral programs, justifying PUC-MG second place.

Although the authors and ECs do not necessarily work together effectively, leading to effective scientific production, the international experience of ECs shows that there is a correlation between research and publication of the work undertaken by ECs. Therefore, the creation of ECs in Brazil, which is relatively new (average of 5 years) (HASHIMOTO, 2012), along with the experience of PUC-MG with the creation of core research on entrepreneurship, can be a way to boost high impact scientific production. 


\section{Main authors}

The ratio of the number of authors per article was most frequently two (47.2\%). About a third of the articles were written by three authors. Regarding the main researchers (see Table 4), Vale from PUC-MG is at the top with nine articles, mainly related to sub-theme networks (or alliances). In second place with four publications is Machado from UEM (sub-theme: entrepreneurship), followed by Nassif (sub-theme: entrepreneurial behavior) who published three articles by Mackenzie and Uninove. Ten authors from different $\mathrm{HEl}$ share the fourth place with two articles each. It is important to note that the vast majority of the authors in entrepreneurship (71.8\%) published only one article in the last 15 years (2000-2014). This suggests that many of the authors do not consider entrepreneurship as their core area of research or that there is still little space for these researchers within TBJA.

Table 4

Major scientific entrepreneurship authors

\begin{tabular}{|c|c|c|c|c|c|c|}
\hline Ranking & Author & Institution & Freq. & $\%$ & $\begin{array}{l}\text { International } \\
\text { production * }\end{array}$ & $\begin{array}{l}\text { Main research } \\
\text { Entrepreneurship? }\end{array}$ \\
\hline 1 & Vale, Gláucia M. V. & PUC-MG & 9 & $6.0 \%$ & 0 & Yes \\
\hline 2 & Machado, Hilka P. V. & UEM & 4 & $2.6 \%$ & 0 & Yes \\
\hline 3 & Nassif, Vânia M. J. & Makenzie/Uninove & 3 & $2.0 \%$ & 0 & Yes \\
\hline \multirow{10}{*}{4} & Alves, Mário A. & FGV-SP & 2 & $1.3 \%$ & 0 & No \\
\hline & Amâncio, Robson & UFLA & 2 & $1.3 \%$ & 0 & No \\
\hline & Borini, Felipe M. & ESPM & 2 & $1.3 \%$ & 1 & No \\
\hline & Corrêa, Victor S. & PUC-MG & 2 & $1.3 \%$ & 0 & Yes \\
\hline & Freitas, Henrique & UFRS & 2 & $1.3 \%$ & 0 & No \\
\hline & Hashimoto, Marcos & FACCAMP & 2 & $1.3 \%$ & 1 & Yes \\
\hline & Martens, Cristina D. P. & Uninove & 2 & $1.3 \%$ & 0 & Yes \\
\hline & Martes, Ana C. B. & FGV-SP & 2 & $1.3 \%$ & 0 & No \\
\hline & Melo, Pedro L. R. & PUC-SP & 2 & $1.3 \%$ & 0 & No \\
\hline & Mendonça, Patrícia M. E. & FEI & 2 & $1.3 \%$ & 0 & No \\
\hline \multirow[t]{2}{*}{5} & Others (1 publication) & & 115 & $76.2 \%$ & & \\
\hline & Total & & 151 & $100.0 \%$ & & \\
\hline
\end{tabular}

Source: Elaborated by the authors.

Note. ${ }^{*}$ It was considered as an international production on entrepreneurship only the journals listed in SJR in Table 2.

Finally, analysis was carried out to see whether the Brazilian authors who published more about entrepreneurship considered this subject as their main field of research. In addition, the analysis sought to identify if these authors have any publication(s) in international journals of entrepreneurship listed in Table 2. The curriculum of the top four best published authors (13 in total) was ranked until 2014. The results indicate (see Table 4) that only two authors Borini (one article in International Entrepreneurship and Management Journal) and Hashimoto (one article in International Journal of Entrepreneurship and Small Business) published in international journals of entrepreneurship. In addition, 53.8\% of the 13 authors listed do not consider entrepreneurship as their main field.

This raises the question: Why do these (53.8\%) authors not consider entrepreneurship as their central focus of research? Why are the remaining authors not considering the international scene? It is true there is no Brazilian secondary data source for entrepreneurship and achieving the top management team is difficult. As a recent field, could not it be a little easier to find interesting research questions for publishing? Of course, for the international scene it is more complicated, but with many international journals there is also a wide range of opportunities. In this sense, for an article to be interesting, the research needs to challenge current assumptions about the phenomenon in question, it needs to oppose common knowledge, challenge well-crafted theory, methods, good fit of data and theory. 


\section{Thematic focus}

Among the 33 different subjects that most aroused authors' interest in entrepreneurship literature in Brazil, the topic 'entrepreneur' leads, accounting for $12.5 \%$ of the publications in the period 2000-2014. This is followed by social entrepreneurship $(11.1 \%)$, networks (8.3\%), entrepreneurial orientation and female entrepreneurship (6.9\%). The topics with less interest were: dynamic, resource base, capital risk, effectuation/causation, corporate entrepreneurship, social stratification and mobility, governance, incubators, innovation, industrial organization, entrepreneurial risk, companies' survival, theory of adaptive probability, creative entrepreneurship, family business and young entrepreneur, as shown in Table 5.

There has been a fragmentation of topics within entrepreneurship in Brazil, with $45.8 \%$ different themes in the Brazilian academy. Maybe, this fragmentation reflects a new field of research. Most of the authors who are publishing in TBJA do not perceive entrepreneurship as a main field of research. Alternatively, it could be argued that Brazilian entrepreneurship research has its own uniqueness or as Landström, Harirchi and Åström (2012) said it is a changeable field linked to disciplines such as management studies.

This study identified potential research areas, aligned with the international and Brazilian context to be explored. For example, entrepreneurial orientation is one of the few areas where the cumulative body of knowledge has been developed (RAUCH, WIKLUND, LUMPKIN et al., 2009), and in Brazil it is an issue studied only in $6.9 \%$ of the articles. Other more recent topics such as entrepreneurship education, international entrepreneurship, offer increasing possibilities for research development. Finally, according to the bibliometric research by Busenitz et al. (2014) with 219 articles, during the period of 2000-2009, in mainstream journals (AMJ, AMR, SMJ, JOM, OS, MS and ASQ), 37\% were related to organizational mode, $17 \%$ to individuals and teams, $14 \%$ to environment, and $12 \%$ to opportunities. Thus, issues related to alliances, networks, organizational arrangements, industry, and other strategic themes within the organizational mode remain important areas for research. Integrating entrepreneurship research and other more established disciplines such as strategy, economics and organizational behavior still have a strong presence in AMJ, AMR, SMJ, JOM, OS, MS and ASQ.

Table 5

\section{Classification of the published articles}

\begin{tabular}{|c|c|c|c|c|}
\hline Ranking & Subject area & Freq. & $\%$ & $\%$ Acum. \\
\hline 1 & Entrepreneur & 9 & $12.5 \%$ & $12.5 \%$ \\
\hline 2 & Social entrepreneurship & 8 & $11.1 \%$ & $23.6 \%$ \\
\hline 3 & Networks & 6 & $8.3 \%$ & $31.9 \%$ \\
\hline \multirow{2}{*}{4} & Entrepreneurial orientation & 5 & $6.9 \%$ & $38.9 \%$ \\
\hline & Female entrepreneurship & 5 & $6.9 \%$ & $45.8 \%$ \\
\hline \multirow{3}{*}{5} & Social capital & 3 & $4.2 \%$ & $50.0 \%$ \\
\hline & Entrepreneurship education & 3 & $4.2 \%$ & $54.2 \%$ \\
\hline & Institutional theory & 3 & $4.2 \%$ & $58.3 \%$ \\
\hline \multirow{5}{*}{6} & Entrepreneurial behavior & 2 & $2.8 \%$ & $61.1 \%$ \\
\hline & Ethical entrepreneurship & 2 & $2.8 \%$ & $63.9 \%$ \\
\hline & Franchise & 2 & $2.8 \%$ & $66.7 \%$ \\
\hline & Internationalization & 2 & $2.8 \%$ & $69.4 \%$ \\
\hline & Economic theory & 2 & $2.8 \%$ & $72.2 \%$ \\
\hline \multirow[t]{2}{*}{7} & $\begin{array}{l}\text { Others: dynamic approach, resource base, capital risk, effectuation/ } \\
\text { causation, corporate entrepreneurship, stratification and social mobility, } \\
\text { governance, incubators, innovation, industrial organization, entrepreneur } \\
\text { profile, companies' survival, theory of adaptive probability, creative } \\
\text { entrepreneurship, family business, young entrepreneur. }\end{array}$ & 20 & $27.8 \%$ & $100.0 \%$ \\
\hline & Total & 72 & $100.0 \%$ & \\
\hline
\end{tabular}

Source: Elaborated by the authors. 
Comparing Brazilian research with the early stage of entrepreneurship research globally, a similarity to point out is the fragmentation within the field. As Brazilian entrepreneurship scholars pursue wide ideas and topics of scope which have some links to the multidisciplinary field, the challenge will be to find out ways to connect this multitude of efforts. The desire is that all entrepreneurship scholars consider offering ways to connect to the broader network of entrepreneurship scholars overall, while these scholars can both speak to the expertise in their narrow community (GARTNER, 2014).

As a high multidisciplinary field, it is of great importance to understand the background and assumptions on which these theories are based and the roots that have been involved. However, if Brazilians researchers fail to do this it can lead Brazilian scholars to both misapply and misinterpret the borrowed theories (LOHRKE and LANDSTRÖM, 2010). As Fayolle (2014, p. 1) pointed out, "a more nuanced view of entrepreneurship is also developing in the area, giving some importance to cognition, intuition, emotion, failure, learning and expertise, and it is become more theory-driven". Researchers have identified entrepreneurial action, its theories, and mechanisms, for example: causation, effectuation, improvisation and bricolage (FAYOLLE, 2014).

\section{Co-citations}

Figure 3 shows a map of co-citations of the most cited works in Brazilian's research articles in TBJA from 2000-2014. Although, Brazilian entrepreneurship scholars are centered with relatively the same references, they can be split into four research domains. Brazilian research use as references the classical entrepreneurship articles. These co-citation works in Brazil have some similarities mainly to the USA (cluster 1 and 2), a little less to Europe (cluster 2) and China (cluster 1 ) comparing to the results of Su, Zhai and Landström (2015). Contrary to China, Brazil does not have its own contextualization. The "Brazilian contextualization" could be interesting for the development of entrepreneurship in the country.

Cluster 1: is a cluster of studies based on social structure and network. The 'strength and weak ties' (GRANOVETTER, 1973 - fourth most cited article), the 'economic action and social structure' (GRANOVETTER, 1985 - third most cited article), and 'structural hole' (BURT, 1992 - sixth most cited article) are central in this cluster. These articles, which underscore the social embeddedness of entrepreneurial behavior, address how networks can influence opportunity recognition, resource acquisition and performance of new ventures

Cluster 2: is a cluster with a group of studies based on classic economics and management theory. One of the ground-breaking studies is Schumpeter (1934), most cited article, who drew scholarly attention to the entrepreneurship field, distinguishing it from traditional economy based on scale, emphasizing entrepreneurship's role in economic development. The seminal study by Shane and Venkataraman (2000), second most cited article, which stimulated an intense debate among scholars about entrepreneurship's domain is also central to this cluster.

Cluster 3: is a cluster related to the entrepreneur and new venture creation. The research by McClelland (1972) analyzes the psychological characteristics that predispose an individual to entrepreneurship, and Gartner (1988) 'who is the entrepreneur?' are the main articles of this cluster. The new venture creation framework integrates four major perspectives: individuals, organizations, environment and process of venture creation (GARTNER, 1985).

Cluster 4: reveals an interest in studying entrepreneurial orientation related to Lumpkin and Dess (1996), fifth most cited article, classifying the construct of entrepreneurial orientation into five multi-dimensions: autonomy, innovativeness, risktaking, proactiveness and competitive aggressiveness, and Miller (1983) whose entrepreneurial orientation has three domains (unidimensional): innovativeness, risk-taking, proactiveness. Great attention here was paid to research methodologies such as qualitative content analysis.

\section{METHODOLOGICAL APPROACH}

Table 6 shows that $75 \%$ of the studies were empirical and $25 \%$ theoretical articles. The empirical studies were classified according to the data source and the purpose of the study. This result shows that the great majority are primary data (collected in the field) by $76.9 \%$, secondary data account for $(11.1 \%)$ and mixed data $(9.3 \%$, collected in the field and secondary data). Regarding the purpose of the study, nearly half of the articles carried out qualitative approach (51.9\%), followed by quantitative approach (37\%). Among the quantitative research using survey ( 20 of 54 ) the main data analysis techniques were: factor analysis 
(21.9\%), regression (18.8\%), percentage analysis (15.6\%) and descriptive (12.5\%). Studies using qualitative and quantitative approaches together were the minority with only $11.1 \%$, indicating opportunities to conduct more research using joint approaches.

Figure 3

\section{Co-citation map of the most cited works by Brazilian research in TBJA}

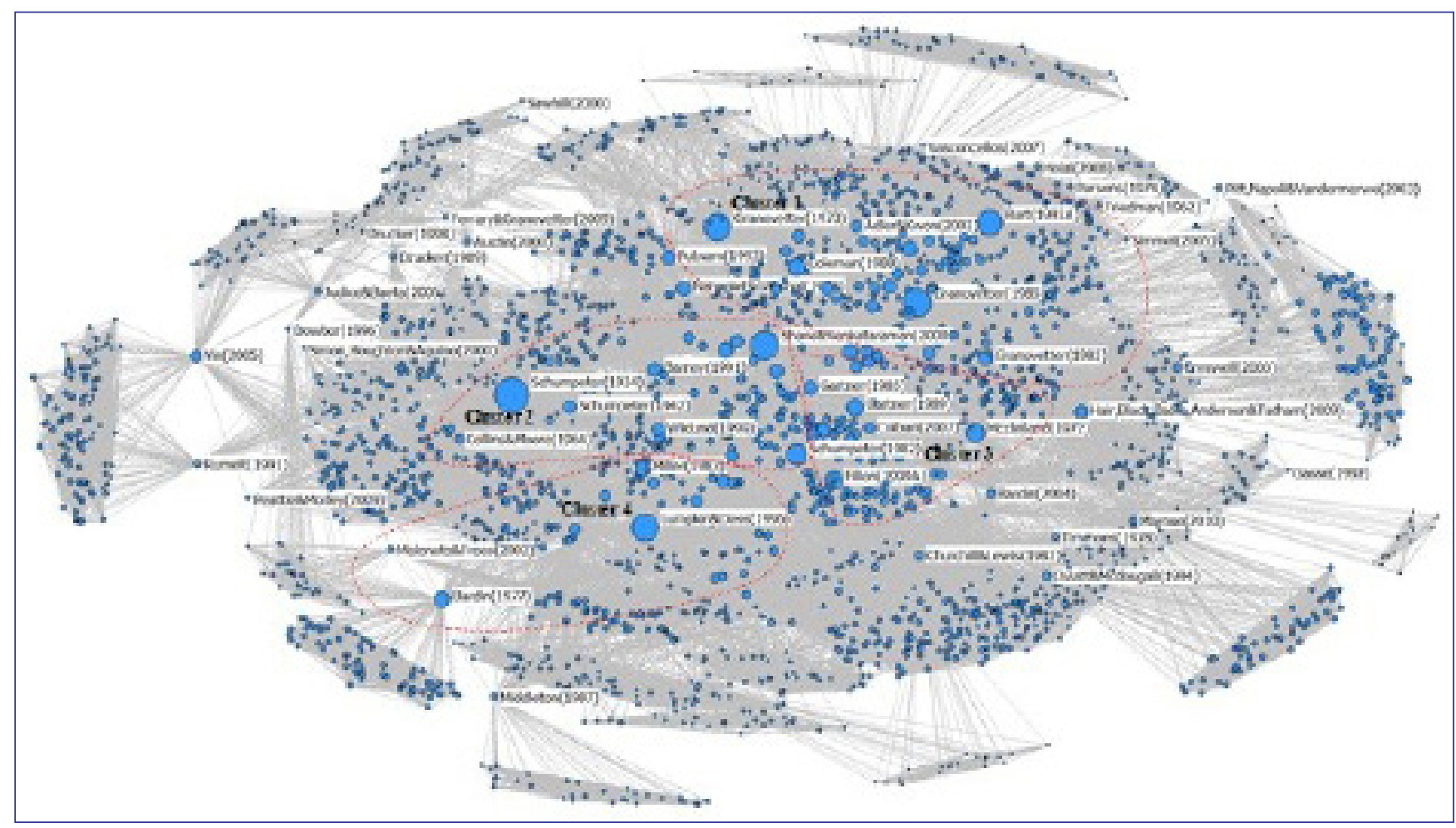

Source: Elaborated by the authors.

Because the hypotheses tested in business strategy and entrepreneurship are complex, and the relationship between industry structure, competitive position and performance are dynamic, it would be interesting to use both qualitative and quantitative approaches together (HARRIGAN, 1983). The benefits of combining qualitative and quantitative methodologies to form a more complete picture of a phenomenon far outweigh the costs of time and effort. The implementation of this more complete methodological strategy, however, requires researchers to become more familiar and comfortable with the ontological, epistemological, and methodological foundations of qualitative and quantitative research (SHAH and CORLEY, 2006).

Regarding the qualitative approach (28 of 54), $60.7 \%$ of the studies conducted interviews, and $52.9 \%$ held 13 or more interviews, showing a relatively good scenario. Although there is not a number defined by the literature, it is generally safe to assume a minimum required interview between 8 and 10, but the principle of "theoretical saturation" is recommended to define the appropriate number of interviews (FISCHER, CASTILHOS and FONSECA, 2014). In this sense, we should pay attention to the number of few interviews (up to 6 ) conducted in seven studies, representing $41.2 \%$ of the total of interviews.

Case studies accounted for $39.3 \%$, and $36.4 \%$ were single cases and only $27.3 \%$ of them were multiple cases. This data indicates opportunities to develop more robust case studies for theoretical development. Theories developed through case studies are important for the novelty, testability, and empirical validation, closely related to the data collected mainly for research in new areas where the existing theories are inadequate. The case study methodology is considered robust if it presents interesting or break off theories passing tests of reliability (EISENHARDT, 1989). However, as noted by Yin (2010) these theories can be restricted to the specific case studied not being very appropriate to generalize due to "scientific rigor" on the method used. 
One way to minimize the limitation of the case study would be the triangulation of theories and replication, in addition to the review of the work by key informants in the case study.

The qualitative research in TBJA could contribute to society by focusing on engaged scholarship as a methodological approach for entrepreneurship research to bridge the gap between theory and practice. Van de Ven and Johnson (2006, p. 803) define engaged scholarship as "a collaborative form of inquiry in which academics and practitioners leverage their different perspectives and competencies to coproduce knowledge about a complex problem or phenomenon that exists under conditions of uncertainty found in the world". How is your scholarship affecting your engagement? Apart from methodological rigor, what are your criteria to evaluate entrepreneurship research? The answers to these questions could be achieved by: (1) scientific and/or technological excellence (relevant to the topic addressed legitimacy). (2) The quality of the research. (3) The impact of the study, engagement, share your knowledge with the society like trying to publish "papers" or "articles" in newspapers or blogs to get closer to the big audience. This kind of research could be very interesting and can be a way of exercising entrepreneurship in practice. However, to get published in top journals, it is necessary to follow the rigor and give contributions to the literature.

Table 6

Methodological indicators of the published articles

\begin{tabular}{|c|c|c|}
\hline Characteristics & Frequency & $\%$ of articles \\
\hline Total & 72 & $100 \%$ \\
\hline Theoretical & 18 & $25.0 \%$ \\
\hline Empirical & 54 & $75.0 \%$ \\
\hline Type of data & 54 & \\
\hline Primary (collected in the field) & 43 & $79.6 \%$ \\
\hline Secondary & 6 & $11.1 \%$ \\
\hline Primary and secondary & 5 & $9.3 \%$ \\
\hline Type of analyses & 54 & \\
\hline Qualitative and quantitative (mixed) & 6 & $11.1 \%$ \\
\hline Quantitative & 20 & $37.0 \%$ \\
\hline Analysis technique & 32 & \\
\hline Factor analyze & 7 & $21.9 \%$ \\
\hline Regression & 6 & $18.8 \%$ \\
\hline Percentage analysis & 5 & $15.6 \%$ \\
\hline Descriptive & 4 & $12.5 \%$ \\
\hline Structural equation modeling & 3 & $9.4 \%$ \\
\hline t teste & 3 & $9.4 \%$ \\
\hline ANOVA & 1 & $3.1 \%$ \\
\hline Longitudinal & 1 & $3.1 \%$ \\
\hline Mean & 1 & $3.1 \%$ \\
\hline Qui-squared test & 1 & $3.1 \%$ \\
\hline Qualitative & 28 & $51.9 \%$ \\
\hline Interviews & 17 & $60.7 \%$ \\
\hline 1 interview & 1 & $5.9 \%$ \\
\hline 2 interviews & 2 & $11.8 \%$ \\
\hline 3 interviews & 2 & $11.8 \%$ \\
\hline 4 interviews & 1 & $5.9 \%$ \\
\hline 6 interviews & 1 & $5.9 \%$ \\
\hline 9 interviews & 1 & $5.9 \%$ \\
\hline 13 interviews or more & 9 & $52.9 \%$ \\
\hline Case study & 11 & $39.3 \%$ \\
\hline Simple & 4 & $36.4 \%$ \\
\hline Double & 4 & $36.4 \%$ \\
\hline Multiple & 3 & $27.3 \%$ \\
\hline
\end{tabular}

Source: Elaborated by the authors. 


\section{Structure of the articles}

When reading and analyzing Brazilian entrepreneurship articles, the largest problem was in the discussion/conclusion, which is usually one of the most relevant parts of an article. The articles presented mere descriptions of the main results, making a connection with the literature. However, most of the authors did not start this section re-affirming the objective of the study, did not mention the theoretical contributions, practical implications, and many of them did not indicate the research's limitations and any suggestions for future research were general with little contribution to the development of theory and further study.

However, what is most impressive when comparing Brazilian and international articles is that the Brazilian articles do not explain the implications of the study. More than half of the articles did not explicitly or clearly report the theoretical contributions, and very few conveyed explicit practices or managerial implications. Regarding the introduction, Brazilian articles do not expose the contributions, which is common practice in international articles. The research question did not appear in most of the Brazilian articles. Although, the practical relevance to the academy is not as important, especially in rigor versus relevance discussion, some of the Brazilian articles have methodological weaknesses.

Writing an article is a crucial step in publishing research work. Structuring articles for success is important to make it a high impact publication, especially because it is a skeleton, acting as a guide, offering a basis for both the reader and the reviewer. While a good structure does not guarantee a good article, high impact articles tend to have a different structure. The emphasis of articles with a high impact is on: (1) the theoretical background (literature review), which sets the context that the problem sits within; and (2) the conclusion and/or discussion, which explore the theoretical contribution and practical implication of the study and how it makes a novel contribution or extends the literature to the existing knowledge base. Although the other sections of the article are relevant, there is a pitiful tendency for some authors to place a lot emphasis on them (SUN and LINTON, 2014). Three main pillars for publishing high-impact articles are: the macro, meso, and micro foundations (FAYOLLE and WRIGHt, 2014):

(1) Macro: the author as an individual (training, values, aspirations) and researcher (monograph or article-based dissertation). (2) Meso: divided into three sub-items. (a) The research question must be interesting, deep (insightful), novel and original, and be familiar with the literature according to the area of investigation (state of the art, gaps, challenges, etc.). (b) The research design with theoretical framework aligning methods and data, showing great level of coherence within the research design. There should be consistency between the research question and design. (c) The research writing as the essence of the research as a way of getting inspiration from the best journals of the field, learning, taking into account multiple experiences by trying to use peers and network members.

(3) Micro: the article(s) should be (a) crucially positioned and show conceptual contribution. (b) Be political: read the journals, cite articles on topic as author maybe reviews. (c) Pay attention to the structure of the article. (d) Justify theory by focusing on the literature review on issues to be covered. (e) If applicable, draw a model diagram. (f) The hypothesis must follow theory, not previous empirical studies. (g) Avoid uninteresting hypothesis and replication. (h) Comprehensive explanation, data justification, connecting to theory and 'industry standard' methods (quantitative), and identify limitations.

\section{CONCLUSION}

This study analyzed the entrepreneurship research in TBJA during the period of 2000-2014. We identified gaps in Brazilian entrepreneurship research and directions for entrepreneurship to get recognition and legitimacy in TBJA and for Brazil's economic and social development through a systematic review of 72 entrepreneurship articles. According to Judge, Cable, Colbert et al. (2007), the impact of an academic text depends in part on the journal's prestige, resulting in the need for researchers to understand what is taking place in Brazilian entrepreneurship, for publication in mainstream journals. Given the difficulty of publishing in top journals, most beginner researchers will be seriously impaired by systems that emphasize a journal's ranking over a high-quality article.

In Brazil, the academic production on entrepreneurship has been marked by the challenges inherent in a relatively new and changing field in searching for an active voice within the academy, which needs to be the subject of critical reflection. For example, within the National Association of Post-Graduate courses in Administration (ANPAD) the field does not have its own 
area, being allocated as a sub-area within Strategy which is quite different to the Academy of Management meeting where entrepreneurship has its own space. In addition, the Brazilian journals focused on entrepreneurship do not have the same prestige as TBJA.

This research identified some main gaps: (1) giving preference to empirical studies carried out by rigorous methodologies, especially with longitudinal, secondary data and experimental design. (2) Conducting studies that can generate theorization or critical analysis. (3) Conducting systematic reviews (qualitative and/or quantitative) or meta-analysis of the literature. (4) Realization of empirical studies that clearly extend the theoretical basis of the existing literature using longitudinal designs in empirical research. (5) Establishing research lines in post-graduate courses (Master and Doctoral) of the HEls focused exclusively on entrepreneurship. Finally, (6) the results reinforce the idea that it is worthwhile for authors to dominate the basics of scientific authorship: generating ideas, theory building and clear writing.

However, this article revealed some important challenges: (1) few entrepreneurship articles published within TBJA compared to others research fields in Brazil. (2) The impact of the scientific production of TBJA is still low compared to the international journals focused exclusively on entrepreneurship. (3) Prevalence of qualitative methodological approaches, in which much of the research is limited to a few interviews and exploratory case studies (single or double). (4) Conclusions characterized by deductive reasoning, without clear presentation of some important points, such as resuming the research objective; lack of explicitly positioning the contribution of the study to theory; absence of practical implications; generic research limitations; and finally, the suggestions for future research are generic.

Comparing some of the challenges set out in this study to the research of Busenitz, Plummer, Klotz et al. (2014), we observed some similarities with the results of the analysis of the 13 seminal entrepreneurial articles during the period of 2000-2010, which were composed of a combination of research approaches. Five of the articles were theoretical, the other five were empirical studies based on secondary data, and three were inductive style research with a limited number of case studies. Less than $40 \%$ of the articles were empirical. Moreover, Busenitz, Plummer, Klotz et al. (2014) indicated that the high-impact articles were within the same conceptual domain and many of them had important implications for many disciplines.

The analyses of opportunities and challenges encountered in this study is not so different from other research fields in Brazil. One way for the entrepreneurial area in Brazil to get more space and legitimacy could be by publishing in good international journals, i.e. from outside to inside. Moreover, some of the most influential and best articles, were written at the beginning of entrepreneurship research. Many of these early contributions are high quality intellectual achievements (LOHRKE and LANDSTRÖM, 2010). In the case of Brazil, it is important to have a close relationship to real entrepreneurs, to the environment and to society. Thus, by knowing the entrepreneurs' experience, knowledge, and empirical evidence it is possible to give a detailed understanding of the phenomenon. Through this deep understanding it is possible to provide an effective insight for building theory, to improve the power, validity, and sophistication of the theoretical models to be developed (LOHRKE and LANDSTRÖM, 2010).

\section{Theoretical and practical contributions}

In theory, this study provides a quantitative and qualitative description, making a critical analysis of the entrepreneurial research, identifying the main challenges and opportunities for the development of future research aiming to help the consolidation and legitimation of entrepreneurship as an important field necessary for the economic and social development of Brazil. Second, in practical terms, by giving a perspective to researchers and first-time authors to produce high impact articles, helping both researchers who see entrepreneurship as a secondary field looking for new opportunities to join definitively in the field, as well as those who are focused on entrepreneurship.

\section{Study implications}

This research has at least two major implications. First, on the scientific rigor, a greater effort is necessary in reducing the historical gap of international insertion of Brazil's main authors of entrepreneurship. One of the main challenges is in terms of methodological guidance changes to get the international scene. For example, research based on qualitative approaches or surveys needs to get close to the level of methodological rigor of the leading international journals. To surpass this challenge, it is suggested here to use methodologies less used in entrepreneurship, such as secondary data, engaged scholarship, and experimental design that is 
widespread in marketing, approaching the most consolidated research techniques from other areas to entrepreneurship. It would also be important to use more advanced technique analysis such as structural equation modeling and longitudinal studies. Thus, we believe that establishing Master and Doctoral Programs in entrepreneurship, the HEls could contribute to a greater impact of Brazilian research in the area, preparing researchers to be able to develop work on entrepreneurship.

The second implication is related to the direction that entrepreneurship intends to follow to become a relevant area within Administration and for Brazil's economic and social development. The results indicate that the Brazilian production of entrepreneurship is still incipient, with little impact on the country. Thus, a great effort from Brazilian authors to develop interesting research is needed, especially for the HEls by forming a critical mass focused on entrepreneurship.

\section{Limitations and future research}

Some limitations of the study should be mentioned. First, this study accessed the articles based on what was published by TBJA, which means that important discussions on the subject during the review process were not captured. Second, by focusing exclusively on TBJA this study may have lost some of the real scenario of the entrepreneurial research in Brazil. However, this focus is important to understand the current state of this research and its impact (BUSENITZ, PLUMMER, KLOTZ et al., 2014). Based on these observations, the first suggestion for future research is (i) the implementation of systematic reviews or bibliometric analysis in journals specialized in entrepreneurship in Brazil as well as journals less well ranked then TBJA.

Second, a qualitative research with the key entrepreneurial authors in Brazil was not developed. Thus, for a better understanding of the vision of the leading authors, it would be interesting (ii) to conduct interviews with the experts on the subject, raising the second suggestion for future research. Third, for space reasons, it was not possible to include all 72 entrepreneurship articles used in this study. Finally, suggestions for future research include an analysis of the social network of the Brazilian authors within TBJA. 


\section{REFERENCES}

AUDRETSCH, D.; THYRIK, R. A model of the entrepreneurial economy. International Journal of Entrepreneurship Education, v. 2, n. 2, p. 143-166, 2004.

AUSTIN, J.; STEVENSON, H.; WEI-SKILLERN, J. Social and commercial entrepreneurship: same, different, or both? Revista de Administração, v. 47, n. 3, p. 370-384, 2012.

BARDIN, L. Análise de conteúdo. Lisboa: Edições 70, 1977.

BARNEY, J. Firm resources and sustained competitive advantage. Journal of Management, v. 17, n. 1, p. 99-120, 1991.

BERTERO, C. O. et al. Produção científica brasileira em administração na década de 2000. Revista de Administração de Empresas, v. 53, n. 1, p. 12-20, 2013.

BREI, V. A.; VIEIRA, V. A.; MATOS, C. A. Meta-análise em marketing. Revista Brasileira de Marketing, v. 13, n. 2, p. 84-97, 2014.

BIRD, B. Implementing entrepreneurial ideas: the case for intention. Academy of Management Review, v. 13, n. 3, p. 442-453, 1988.

BURT, R. S. Structural holes: the social structure of competition. Cambridge: Harvard University Press, 1992.

BUSENITZ, L. W. et al. Entrepreneurship research (1985-2009) and the emergence of opportunities. Entrepreneurship Theory and Practice, v. 38, n. 5, p. 981-1000, 2014.

COORDENAÇÃO DE APERFEIÇOAMENTO DE PESSOAL DE NÍVEL SUPERIOR - CAPES. Avaliação da pós-graduação. 2012. Available at: <http://www.capes.gov.br/avaliacao/avaliacao-da-pos-graduacao>. Accessed on: 28 Mar. 2012.

COVIN, J. G.; GREEN, K. M.; SLEVIN, D. P. Strategic process effects on the entrepreneurial orientation-sales growth rate relationship. Entrepreneurship Theory and Practice, v. 30, n. 1, p. 57-81, 2006.

COVIN, J. G.; LUMPKIN, G. T. Entrepreneurial orientation theory and research: reflections on a needed construct. Entrepreneurship Theory and Practice, v. 35, n. 5, p. 855-872, 2011.

COVIN, J. G.; SLEVIN, D. P. Strategic management of small firms in hostile and benign environments. Strategic Management Journal, v. 10, n. 1, p. 75-87, 1989.

DEES, J. G. The meaning of "Social entrepreneurship". Durham: Fuqua, 1998. Available at: <http://www.fuqua.duke.edu/centers/ case/>. Accessed on: 16 Sept. 2018.

EISENHARDT, K. M. Building theories from case study research. Academy of Management Review, v. 14, n. 4, p. 532-550, 1989.

FISCHER, E.; CASTILHOS, R. B.; FONSECA, M. J. Entrevista qualitativa na pesquisa de marketing e do consumidor: abordagens pragmáticas e orientações. Revista Brasileira de Marketing, v. 13, n. 4, p. 67-79, 2014.

FAYOLLE, A. Handbook of research on entrepreneurship: what we know and what we need to know. Cheltenham: Edward Elgar, 2014.

FAYOLLE, A.; WRIGHT, M. How to get published in the best entrepreneurship journals: a guide to steer your academic career. Cheltenham: Edward Elgar, 2014.

GARTNER, W. B. A conceptual framework for describing the phenomenon of new venture creation. The Academy of Management Review, v. 10, n. 4, p. 696-706, 1985.
GARTNER, W. B. Who is an entrepreneur? Is the wrong question. Entrepreneurship Theory and Practice, v. 14, n. 1, p. 47-68, 1988.

GARTNER, W. B. Organizing entrepreneurship (research). In: FAYOLLE, A. Handbook of research on entrepreneurship: what we know and what we need to know. Cheltenham: Edward Elgar, 2014.

GRANOVETTER, M. S. The strength of weak ties. American Journal of Sociology, v. 78, n. 6, p. 1360-1380, 1973.

GRANOVETTER, M. S. Economic action and social structure: the problem of embeddedness. American Journal of Sociology, v. 91, n. 3, p. 481-510, 1985.

GRANOVETTER, M. S. The impact of social structure on economic outcomes. Journal of Economic Perspectives, v. 19, n.1, p. 33-50, 2005.

GODÓI-DE-SOUZA, E.; FISCHER, R. M. The succession process at social enterprises in Brazil. Revista de Adminitração, v. 47, n. 3, p. 473-488, 2012.

HARRIGAN, K. R. Methodologies for contingency approaches to business strategy. The Academy of Management Review, v. 8 , n. 3, p. 398-405, 1983.

HASHIMOTO, M. Centros de empreendedorismo acadêmicos no Brasil: uma análise contextualizada. São Paulo: SEBRAE-SP, 2012.

INÁCIO JÚNIOR, E. et al. From 1980 to 2010: an overview about the Brazilian scientific production in entrepreneurship. International Journal of Entrepreneurship, v. 18, n. 1, p. 129-141, 2014.

JACSÓ, P. The need for end-user customization of the journal sets of the subject categories in the SCImago journal ranking database for more appropriate league lists. A case study for the library \& information science field. El Profesional de la Información, v. 22, n. 5, p. 459-473, 2013.

JUDGE, T. A. et al. What causes a management article to be cited: article, author or journal? Academy of Management Journal, v. 50, n. 3, p. 491-506, 2007.

LANDSTRÖM, H.; BENNER, M. Entrepreneurship research: a history of scholar migration. In: LANDSTRÖM, H.; LOHRKE, F. Historical foundations of entrepreneurship research. Cheltebham: Edward Elgar, 2010.

LANDSTRÖM, H.; HARIRCHI, G.; ÅSTRÖM, F. Entrepreneurship: exploring the knowledge base. Research Policy, v. 41, n. 7, p. $1154-$ 1181, 2012.

LOHRKE, F.; LANDSTRÖM, H. History matters in entrepreneurship research. In: LANDSTRÖM, H.; LOHRKE, F. Historical foundations of entrepreneurship research. Cheltebham: Edward Elgar, 2010.

LORZ, M.; MULLER, S.; VOLERY, T. Entrepreneurship education: a systematic review of the methods in impact studies. Journal of Enterprising Culture, v. 21, n. 2, p. 123-151, 2013.

LUMPKIN, G. T.; DESS, G. G. Clarifying the entrepreneurial orientation construct and linking it to performance. Academy of Management Review, v. 21, n. 1, p. 135-172, 1996.

MCCLELLAND, D. C. The achieving society. Princeton: van Nostrand, 1961. 
Entrepreneurship research (2000-2014) in the top six Brazilian journals of administration: gaps and directions
Antonio Benedito de Oliveira Junior | Cristiane Chaves Gattaz Roberto Carlos Bernardes | Edson Sadao lizuka
MCCLELLAND, D. C. A sociedade competitiva. Rio de Janeiro: Expressão e Cultura, 1972.

MILLER, D. The correlates of entrepreneurship in three types of firms. Management Science, v. 29, n. 7, p. 770-791, 1983.

MILLER, D.; FRIESEN, P. Innovation in conservative and entrepreneurial firms: two models of strategic momentum. Strategic Management Journal, v. 3, n. 1, p. 1-25, 1982.

MUTHAMILARASAN, M.; PRASAD, M. Impact of impact factor in quantifying the quality of scientific research. Current Science, v. 107, n. 8, p. 1233-1234, 2014.

OLIVEIRA JUNIOR, A. B. et al. Impact of entrepreneurial orientation on strategic alliances and the role of top management. Revista de Administração de Empresas, v. 56, n. 3, p. 315-329, 2016.

PETTICREW, M.; ROBERTS, H. Systematic reviews in the social sciences: a practical guide. Oxford: Blackwell, 2006.

$\mathrm{RAUCH}, \mathrm{A}$. et al. Entrepreneurial orientation and business performance: an assessment of past research and suggestions for the future. Entrepreneurship Theory and Practice, v. 33, n. 3, p. 761-787, 2009.

SANTOS, S. C. et al. The emergence of entrepreneurial behaviour: intention, education and orientation. Cheltebham: Edward Elgar, 2017.

SCIMAGO JOURNAL RANK-SJR. From SCImago Journal Rank website. 2017. Disponível em: <http://www.scimagojr.com/journalrank. php?area=1400\&country=BR\&year=2015>. Accessed on: 04 Apr. 2017.

SCIMAGO JOURNAL RANK -SJR. From SCImago Journal Rank website. 2017a. Available at: <http://www.scimagojr.com/journalsearch. php?q=entrepreneurship>. Accessed on: 04 Apr. 2017.
SHANE, S.; VENKATARAMAN, S. The promise of entrepreneurship as a field of research. Academy of Management Review, v. 25, n. 1, p. 217-226, 2000.

SHAH, S. K.; CORLEY, K. G. Building better theory by bridging the quantitative-qualitative divide. Journal of Management Studies, v. 43, n. 8, p. 1821-1835, 2006.

SCHUMPETER, J. A. The theory of economic development: an inquiry into profits, capital, credit, interest, and the business cycle. New Brunswick: Transaction, 1934.

STEVENSON, H. H.; JARILLO, J. C. A paradigm of entrepreneurship: entrepreneurial management. Strategic Management Journal, v. 11, n. 4, p. 17-27, 1990.

SU, J.; ZHAI, Q.; LANDSTRÖM, H. Entrepreneurship research in China: internationalization or contextualization? Entrepreneurship \& Regional Development, v. 27, n. 1-2, p. 1-32, 2015.

SUN, H.; LINTON, J. D. Structuring papers for success: making your paper more like a high impact publication than a desk reject. Technovation, v. 34, n. 10, p. 571-573, 2014.

VAN DE VEN, A. H.; JOHNSON, P. E. Knowledge for theory and practice. Academy of Management Review, v. 31, n. 4, p. 802-821, 2006.

YAMAKAWA, E. K. et al. Comparativo dos softwares de gerenciamento de referências bibliográficas: Mendeley, EndNote e Zotero. TransInformação, v. 26, n. 2, p. 167-176, 2014.

YIN, R. K. Estudo de caso: planejamento e métodos. 4. ed. Porto Alegre: Bookman, 2010.

Antonio Benedito de Oliveira Junior

Doctor in Business Administration from University Center FEI (FEI), partially completed at Arizona State University (ASU); Coordinator of Graduation Programs of the Distance Education Laureate International Universities at Anhembi Morumbi University (UAM) and Coordinator of Post-Graduation Programs of the Distance Education Laureate International Universities at Faculdades Metropolitanas Unidas (FMU), São Paulo - SP, Brazil; Assistant Professor of the Distance Education Laureate International Universities at UAM and FMU, São Paulo - SP, Brazil. E-mail: abojunior@hotmail.com

Cristiane Chaves Gattaz

Doctor in Production Engineering from University of São Paulo (USP); Post-Doctorate in Business Administration from University Center FEI (FEI), São Paulo - SP, Brazil. E-mail: cristiane.gattaz@gmail.com

Roberto Carlos Bernardes

Doctor in Sociology from University of São Paulo (USP); Professor of the Post-Graduation Program in Administration from University Center FEI (FEI), São Paulo - SP, Brazil.E-mail: bernardes@fei.edu.br

Edson Sadao lizuka

Doctor in Public Administration and Government from the School of Business Administration of São Paulo at Fundação Getúlio Vargas (FGV EAESP); Professor of the Post-Graduation Program in Administration from University Center FEI (FEI), São Paulo - SP, Brazil. E-mail: esadao@fei.edu.br 